SCADidoc

International Journal of Dentistry and Oral Science (IJDOS)

ISSN: 2377-8075

\title{
Comparative Evaluation Of Different Concentrations Of Povidone Iodine As Subgingival Irrigant In The Management Of Chronic Periodontitis
}

Research Article

Karthik $\mathrm{V}^{1}$, Arvina Rajasekar ${ }^{2}$

${ }^{1}$ Graduate Student, Saveetha Dental College and Hospitals, Saveetha Institute of Medical and Technical Sciences (SIMATS), Saveetha University, Chennai- 77 , India.

${ }^{2}$ Senior Lecturer, Department of Periodontics, Saveetha Dental College and Hospitals, Saveetha Institute of Medical and Technical Sciences [SIMATS], Saveetha University, Chennai- 77, India.

\section{Abstract}

Background: Mechanical plaque control is the first line of management of chronic periodontitis. In recent years, a variety of adjuncts including irrigants, chemical plaque controlling agents, vitamin supplements, systemic and local antibiotics, local drug delivery, herbal extracts, probiotics are gaining importance. Povidone iodine is one of the most broad spectrum and potent antiseptics available at various concentrations.

Aim: The aim of the study was to assess and compare the efficacy of various concentrations of povidone iodine as sub gingival irrigant in the management of chronic periodontitis.

Materials And Methods: The present double blinded, parallel designed, randomized clinical trial was carried out in the Department of Periodontics, Saveetha Dental College and Hospitals, Chennai, India. A total of 66 patients with generalised chronic periodontitis (22 participants in each group [Group 1 (povidone iodine 2\%), Group 2 (povidone iodine 10\%) and Group 3 (povidone iodine $0.1 \%$ )]) were enrolled. Scaling and root planing was done for all the participants and then the pocket was irrigated with respective irrigant. The clinical parameters including Loe and Silness Gingival Index (GI) and Probing Pocket Depth (PPD) were recorded at baseline and after 1 month. The data was analyzed using Statistical Package for Social Sciences (SPSS Software, Version 23.0). One-way ANOVA was used to compare the mean values of GI and PPD between the groups. Tukey's HSD post hoc test was done to find means that are significantly different from each other. Also, student's paired t-test was used to compare the mean values of GI and PPD within the groups.

Results: One-way ANOVA showed that there was no statistically significant difference between the baseline GI and PPD values as compared to the three mouthwash groups $(p=0.865)$, but there was a statistically significant difference $(p=0.000)$ observed between the three concentrations when compared after 1 month. Student's paired t-test showed that the difference between the baseline and post GI and baseline and the post PPD was statistically significant in both Group 1 and Group 2 with the $\mathrm{p}$ value of 0.000 .

Conclusion: Significant improvement in gingival index and pocket depth suggests that subgingival povidone iodine irrigation could be an effective adjunct to scaling and root planing in the management of chronic periodontitis. Also, as the concentration of povidone iodine increases, the improvement in clinical parameters also increases.

Keywords: Povidone Iodine; Pocket Depth; Innovative; Gingivitis; Periodontitis; Subgingival Irrigation.

\section{Introduction}

Periodontitis is a chronic inflammatory disease of the oral cavity which affects both the soft and hard tissues. If it is left untreated, it leads to increased pocket depth, clinical attachment loss, recession, mobility, bone loss, pathologic migration of the teeth and tooth loss [1-5]. It is a multifactorial disease. Even though plaque is the primary etiology, the disease is aggravated by a variety of risk factors including age, systemic diseases, gender, genetic factors, smoking, stress, hormones [6-15].

Scaling and root planing (SRP) therapy is considered as the gold

*Corresponding Author:

Dr. Arvina Rajasekar,

Senior Lecturer, Department of Periodontics, Saveetha Dental College and Hospitals, Saveetha Institute of Medical and Technical Sciences [SIMATS], Saveetha University, Chennai- 77 , India.

Tel: +919486442309

E-mail: arvinar.sdc@saveetha.com

Received: September 13, 2021

Accepted: September 22, 2021

Published: September 23, 2021

Citation: Karthik V, Arvina Rajasekar. Comparative Evaluation Of Different Concentrations Of Povidone Iodine As Subgingival Irrigant In The Management Of Chronic Periodontitis. Int J Dentistry Oral Sci. 2021;8(9):4606-4610. doi: http://dx.doi.org/10.19070/2377-8075-21000938

Copyright: Dr. Arvina Rajasekar ${ }^{\circ} 2021$. This is an open-access article distributed under the terms of the Creative Commons Attribution License, which permits unrestricted use, distribution and reproduction in any medium, provided the original author and source are credited. 
standard for periodontal disease [16]. However, SRP is subjected to certain restrictions, such as the failure to insert deeper periodontal pockets, bifurcations and the failure to eliminate microorganisms because of their tissue invading nature $[17,19]$. To overcome this, variety of adjuncts including irrigants, chemical plaque controlling agents, vitamin supplements, systemic and local antibiotics, local drug delivery, herbal extracts, probiotics and LASER are gaining importance.

Irrigants are effective at flushing out plaque, bacteria and their toxins that become trapped in the small spaces between teeth and under the gumline, preventing the buildup of harmful bacteria. The most widely studied subgingival irrigants are chlorhexidine and various concentrations of povidone iodine solution [20]. Chlorhexidine (CHX) is considered a "gold standard" antibacterial solution and is extensively used as a mouthwash and irrigating solution [21]. However, it has certain side effects on long term usage such as loss of taste sensation, staining of the teeth and in some cases, parotid swelling. Povidone iodine is the most broadspectrum and potent antiseptic available [22].

It has a bactericidal effect against most bacteria including putative periodontal pathogens, fungi, mycobacteria, viruses, and protozoa. Povidone-iodine remains an effective antibacterial agent when used directly into the periodontal pocket even at low concentrations [23].

Elemental iodine or its derivatives polyvinylpyrrolidone-iodine complex (Povidone-I) is the most broad-spectrum and potent antiseptics available. This Povidone-I has a bactericidal effect against most bacteria including putative periodontal pathogens, fungi, mycobacteria, viruses, and protozoa [24, 25]. Povidoneiodine remains an effective antibacterial agent when used directly into the periodontal pocket even at low concentrations $[26,16]$. Recent studies had used $0.1 \%$ Povidone iodine as sub gingival irrigant and compared the antimicrobial efficacy and also it had shown that, when $2 \%$ concentration of povidone iodine is used as a subgingival irrigant there is a increased antimicrobial activity with reduced gingival inflammation [17].

Our team has extensive knowledge and research experience that has translated into high quality publications [27-46]. Through extensive literature search, it was revealed that there is a lack of adequate studies comparing various concentrations of povidone iodine as sub gingival irrigant in the management of chronic periodontitis. In this context, the aim of the study was to assess and compare the efficacy of various concentrations of povidone iodine as sub gingival irrigant in the management of chronic periodontitis.

\section{Materials and Methods}

\section{Study Population:}

The present double blinded, parallel designed, randomized clinical trial was carried out in the Department of Periodontics, Saveetha Dental College and Hospitals, Chennai, India. A total of 66 patients with generalised chronic periodontitis were enrolled. The ethical clearance was obtained from the Institutional Ethical Committee and a written informed consent was obtained from all the study participants.

\section{Inclusion Criteria:}

Participants within the age group of 20-25 were systematically healthy, presence of at least 20 teeth, probing depth of 4-5 mm, presence of bleeding on probing (BOP) in at least $30 \%$ of the sites were included in the study.

\section{Exclusion Criteria:}

Participants who were under orthodontic treatment, smokers, pregnant or lactating mothers, patients under long term medications, systemically compromised patients were excluded from the study.

\section{Test group:}

Group 1: Povidone iodine $2 \%$

Group 2: Povidone iodine $10 \%$

Group 3: Povidone iodine $0.1 \%$

\section{Study Design:}

The sample size was 66 with 22 participants in each group [Group 1 (povidone iodine 2\%), Group 2 (povidone iodine 10\%) and Group 3 (povidone iodine 0.1\%)]. Participants were assigned to the groups by a person not involved in the study. Scaling and root planing was done for all the participants using Gracey curettes and then the pocket was irrigated with respective irrigant using a syringe. The syringe was gently inserted into the depth of periodontal pockets to assure delivery of irrigant solution. Repeated irrigation ensured that irrigant solution filled up pockets for a period of $5 \mathrm{~min}$ and oral hygiene instructions were reinforced. The clinical parameters including Loe and Silness Gingival Index (GI) and Probing Pocket Depth (PPD) were recorded (baseline). All the subjects were recalled after 1 month and the same parameters were recorded.

\section{Statistical Analysis:}

The data was analyzed using Statistical Package for Social Sciences (SPSS Software, Version 23.0). Descriptive and inferential statistics were done for data summarization and presentation. One-way ANOVA was used to compare the mean values of GI and PPD between the groups. Tukey's HSD post hoc test was done to find means that are significantly different from each other. Also, student's paired t-test was used to compare the mean values of GI and PPD within the groups.

\section{Results}

A total of 66 study participants were enrolled in this study and were divided into three groups each of 22 participants. Group 1 $2 \%$ povidone iodine, Group 2 - 10\% povidone iodine and Group $3-0.1 \%$ povidone iodine.

One-way ANOVA showed there was no statistically significant difference between the baseline GI and PPD values as compared to the three mouthwash groups $(p=0.865)$, but there was a statistically significant difference $(\mathrm{p}=0.000)$ observed between the three concentrations when compared after 1 month. The baseline 
values between the three groups were statistically not significant $(p=0.865)$, whereas after 1 month, there was a statistically significant difference $(\mathrm{p}=0.000)$. (Table 1$)$.

Tukey's HSD post hoc test was done to find means that are significantly different from each other. A statistically significant difference between Group 1 and Group 3 was observed in terms of post GI $(p=0.000)$ and post PPD $(p=0.000)$ but statistically no significant difference was observed between Group 1 and Group 2 in terms of post $G I(p=0.171)$ and post PPD $(p=0.338)$. (Table 2).

Student's paired t-test was done to compare the mean values of GI and PPD within the groups. The mean difference between the baseline and post GI and baseline and the post PPD was statistically significant in both Group 1 and Group 2 with the p value of 0.000 . Whereas, no statistically significant difference was observed between the baseline and post GI (0.24) and baseline and post PPD (0.27) in Group 3. (Table 3).

\section{Discussion}

The present study was done to assess the different concentrations of povidone iodine as a subgingival irrigant in the management of chronic periodontitis.

The present study showed that the mean PPD at baseline was statistically not significant between the three groups $(p=0.47)$. However, the mean PPD after 1 month was highly significant between $2 \%$ povidone iodine and $0.1 \%$ povidone iodine $(\mathrm{p}=0.000)$ and $10 \%$ povidone iodine and $0.1 \%$ povidone iodine $(\mathrm{p}=0.000)$; showing that both $2 \%$ povidone iodine and $10 \%$ povidone iodine were equally effective in preventing plaque formation $(\mathrm{p}=0.338)$. Selvagii et al., studied the clinical efficacy of povidone iodine as a subgingival irrigant and observed that there was a significant reduction in pocket depth after one month of usage [47]. Hoang et al., revealed that there are three main mechanisms such as antiinflammatory, antiseptic and bone formation through which povidone iodine is effective in reducing periodontitis [48].

Also, the present study revealed that the mean GI after 1 month was highly significant between $2 \%$ povidone iodine and $0.1 \%$

Table 1. One-way ANOVA comparison of mean GI and PPD between the study groups.

\begin{tabular}{|c|c|c|c|c|}
\hline Variable & $\begin{array}{c}\text { Group 1 } \\
\mathbf{( 2 \%} \text { povidone iodine })\end{array}$ & $\begin{array}{c}\text { Group 2 } \\
\mathbf{( 1 0 \% \text { povidone }} \\
\text { iodine })\end{array}$ & $\begin{array}{c}\text { Group 3 } \\
\mathbf{( 0 . 1 \% \text { povidone }} \\
\text { iodine })\end{array}$ & p value \\
\hline Pre GI & $2.681 \pm 1.037$ & $3.409 \pm 1.543$ & $3.5 \pm 1.144$ & 0.865 \\
\hline Post GI & $1.409 \pm 1.225$ & $1.476 \pm 1.081$ & $2.343 \pm 1.1154$ & 0 \\
\hline Pre PPD & $4.54 \pm 1.33$ & $4.8 \pm 1.012$ & $4.36 \pm 1.000$ & 0.47 \\
\hline Post PPD & $0.76 \pm 0.36$ & $1.05 \pm 1.65$ & $2.30 \pm 1.479$ & 0 \\
\hline
\end{tabular}

Table 2. Tukey's HSD post Hoc pairwise comparison of mean GI and PPD.

\begin{tabular}{|c|c|c|c|c|c|}
\hline \multicolumn{2}{|r|}{ Groups } & \multicolumn{2}{|c|}{ Post GI } & \multicolumn{2}{|c|}{ Post PPD } \\
\hline & & Mean difference & $p$ value & Mean difference & p value \\
\hline \multirow{2}{*}{$\begin{array}{c}\text { Group } \\
1(2 \% \\
\text { povidone } \\
\text { iodine })\end{array}$} & $\begin{array}{c}\text { Group } 2(10 \% \text { povidone } \\
\text { iodine })\end{array}$ & -0.067 & 0.171 & -0.29 & 0.338 \\
\hline & $\begin{array}{c}\text { Group } 3 \\
(0.1 \% \text { povidone iodine })\end{array}$ & -0.934 & 0 & -1.54 & 0 \\
\hline \multirow{2}{*}{$\begin{array}{c}\text { Group } \\
2(10 \% \\
\text { povidone } \\
\text { iodine })\end{array}$} & $\begin{array}{c}\text { Group } 1(2 \% \text { povidone } \\
\text { iodine })\end{array}$ & 0.067 & 0.171 & 0.29 & 0.338 \\
\hline & $\begin{array}{c}\text { Group } 3 \\
(0.1 \% \text { povidone iodine })\end{array}$ & -0.867 & 0 & -1.25 & 0 \\
\hline
\end{tabular}

Table 3. Mean comparison of GI and PPD within the study groups using student's paired t-test.

\begin{tabular}{|c|c|c|c|c|c|c|}
\hline \multirow{2}{*}{ Groups } & \multicolumn{2}{|c|}{ Mean GI } & \multirow{2}{*}{ p value } & \multicolumn{2}{c|}{ Mean PPD } & p value \\
\cline { 2 - 3 } \cline { 5 - 6 } & Pre & Post & & Pre & Post & \\
\hline $\begin{array}{c}\text { Group 1 (2\% povi- } \\
\text { done iodine) }\end{array}$ & $2.681 \pm 1.037$ & $1.409 \pm 1.225$ & 0 & $4.54 \pm 1.33$ & $0.76 \pm 0.36$ & 0 \\
\hline $\begin{array}{c}\text { Group 2 (10\% } \\
\text { povidone iodine) }\end{array}$ & $3.409 \pm 1.543$ & $1.476 \pm 1.081$ & 0 & $4.8 \pm 1.012$ & $1.05 \pm 1.65$ & 0 \\
\hline $\begin{array}{c}\text { Group 3 (0.1\% } \\
\text { povidone iodine) }\end{array}$ & $3.5 \pm 1.144$ & $2.343 \pm 1.1154$ & 0.24 & $4.36 \pm 1.000$ & $2.30 \pm 1.479$ & 0.27 \\
\hline
\end{tabular}


povidone iodine $(\mathrm{p}=0.000)$ and $10 \%$ povidone iodine and $0.1 \%$ povidone iodine $(\mathrm{p}=0.000)$; showing that both $2 \%$ povidone iodine and $10 \%$ povidone iodine were equally effective in reducing inflammation $(\mathrm{p}=0.171)$. This might be due to the substantivity of $2 \%$ povidone iodine and $10 \%$ povidone iodine, which adhere to the tissues such as oral mucosa and teeth. This helps to maintain a potent sustained release, which, in turn, reduces the bacterial count and prevents the accumulation of dental plaque and so the gingivitis.

Berkelmen et al., studied the clinical efficacy of povidone iodine towards periodontitis and revealed that there was a reduction in pocket depth after one month of usage [49]. Sindhura $\mathrm{H}$ et al., studied the clinical efficacy of $0.1 \%$ of povidone iodine and showed significant reduction in gingival index scores after 1 month of usage [17]. Similar results were obtained in the studies of Perayil et al., [50] and Eid Alroudhan et al., [51]. Our findings are in accordance with the previous studies.

From the study results, it can be stated that $10 \%$ povidone iodine showed significant improvement in gingival index and pocket depth and hence it could be an effective adjunct to scaling and root planing in the management of chronic periodontitis. Also, as the concentration of povidone iodine increases, the improvement in clinical parameters also increases. However, further long term follow-up studies are needed to substantiate the present finding and hence can be used as an adjunct to scaling and root planning in the management of periodontal diseases.

\section{Conclusion}

Significant improvement in gingival index and pocket depth suggests that subgingival povidone iodine irrigation could be an effective adjunct to scaling and root planing in the management of chronic periodontitis. Also, as the concentration of povidone iodine increases, the improvement in clinical parameters also increases.

\section{Acknowledgement}

The authors would like to acknowledge the help rendered by Saveetha Dental College and Hospitals, Saveetha Institute of Medical and Technical Sciences, Saveetha University, Chennai.

\section{Funding}

The present project is funded by

- Saveetha Institute of Medical and Technical sciences

- Saveetha Dental college and Hospitals

- Saveetha University

- VKK building contractors

\section{References}

[1]. Rajeshwaran N, Rajasekar A, Kaarthikeyan G. Prevalence of Pathologic Migration in Patients with Periodontitis: A Retrospective Analysis. J. Complement. Med. Res. 2020;11(4):172-8.

[2]. KARTHIKEYAN MURTHYKUMAR DR, KAARTHIKEYAN DG. Prevalence of Tooth Loss Among Chronic Periodontitis Patients-A Retrospective Study. Int. J. Pharm. Res. 2020 Jul;12(2).

[3]. Murthykumar K, Rajasekar A, Kaarthikeyan G. Assessment of various treatment modalities for isolated gingival recession defect- A retrospective study.
Int. j. res. pharm. sci. 2020;11: 3-7.

[4]. Sabarathinam J, Rajasekar A, Madhulaxmi M. Prevalence of Furcation Involvement Among Patients with Periodontitis: A Cross Sectional Study. Int. j. res. pharm. sci. 2020;11:1483-7.

[5]. Rajeshwaran N, Rajasekar A. Prevalence of Angular Bone Defects in Chronic Periodontitis Patients with and without Systemic Diseases. Indian J. Forensic Med. Toxicol. 2020 Oct 1;14(4).

[6]. B G, Geethika B, Rajasekar A, Chaudary M. Comparison of periodontal status among pregnant and non-pregnant women. Int. j. res. pharm. sci. 2020;11: 1923-6.

[7]. Rajasekar A, Lecturer S, Department of Periodontics, Saveetha Dental College and Hospitals, Saveetha Institute of Medical and Technical Sciences, Saveetha University, et al. Assessment Of Periodontal Status among Post Menopausal Women: A Retrospective Study. Int. J. Dent. Oral Sci. 2020: 1063-6.

[8]. Kandhan TS, Rajasekar A. Prevalence of Periodontal Diseases Among Patients with And Without Systemic Diseases-A Retrospective Study. J. Complement. Med. Res. 2020;11(4):155-62.

[9]. Assessment of periodontal health among patients with diabetes mellitus: a retrospective study. J. contemp. issues bus. gov. 2021;26.

[10]. SHAH P, RAJASEKAR A, CHAUDHARY M. Assessment of Gender Based Difference in Occurrence of Periodontal Diseases: A Retrospective Study. J. contemp. issues bus. gov. $2021 \mathrm{Feb}$ 16;27(2):521-6.

[11]. MOHD AZLAN SUNIL NS, RAJASEKAR A, DURAISAMY R. Evaluation of Periodontal Health Adjacent to Class V Restoration. J. contemp. issues bus. gov. $2021 \mathrm{Feb}$ 15;27(2):324-9.

[12]. RAJASEKAR A, CHAUDARY M. Prevalence of Periodontal Diseases Among Individuals Above 45 Years: A Retrospective Study. J. contemp. issues bus. gov. $2021 \mathrm{Feb} 19 ; 27(2): 527-33$.

[13]. Rajasekar A, Mathew MG. Prevalence of Periodontal Disease among Individuals between 18-30 Years of Age: A Retrospective Study. Ann Med Health Sci Res. 2021 Jun 30.

[14]. S TA, Thanish AS, Rajasekar A, Mathew MG. Assessment of tooth loss in chronic periodontitis patients with and without diabetes mellitus: A crosssectional study. Int. j. res. pharm. sci. 2020;11: 1927-31.

[15]. Evaluation of Antiplaque and Antigingivitis Effects of A Herbal Mouthwash. Int. J. Pharm. Res. 2021;13.

[16]. Cobb CM. Clinical significance of non-surgical periodontal therapy: an evidence-based perspective of scaling and root planing. J Clin Periodontol. 2002 May;29 Suppl 2:22-32.Pubmed PMID: 12010523.

[17]. Sindhura H, Harsha RH, Shilpa RH. Efficacy of subgingival irrigation with $10 \%$ povidone-iodine as an adjunct to scaling and root planing: A clinical and microbiological study. Indian J Dent Res. 2017 Sep 1;28(5):514.

[18]. Anandakumar S, Malaiappan S. Effect of Subgingival Irrigation with Natural Products as an Adjunct to Scaling and Root Planing in the Treatment of Chronic Periodontitis-A Systematic Review. J. Clin. Diagnostic Res. 2018 Aug $1 ; 12(8)$.

[19]. Pihlstrom BL, Michalowicz BS, Johnson NW. Periodontal diseases. The lancet. 2005 Nov 19;366(9499):1809-20.

[20]. Axelsson P, Lindhe J. Efficacy of mouthrinses in inhibiting dental plaque and gingivitis in man. J Clin Periodontol. 1987 Apr;14(4):205-12.

[21]. Torkan S. Comparison of the effects of an herbal mouthwash with chlorhexidine on surface bacteria counts of dental plaque in dogs. Biosci. Biotechnol. Res. Asia. 2015;12(1):955-9.

[22]. Bhat N, Mitra R, Oza S, Mantu VK, Bishnoi S, Gohil M, et al. The antiplaque effect of herbal mouthwash in comparison to chlorhexidine in human gingival disease: a randomized placebo controlled clinical trial. J. Complement. Integr. Med. 2014 Jun 1;11(2):129-37.

[23]. Umeda M, Takeuchi Y, Noguchi K, Huang Y, Koshy G, Ishikawa I. Effects of nonsurgical periodontal therapy on the microbiota. Periodontol 2000. 2004 Oct;36(1):98-120.

[24]. Umeda M, Miwa Z, Takeuchi Y, Ishizuka M, Huang Y, Noguchi K, et al. The distribution of periodontopathic bacteria among Japanese children and their parents. J Periodontal Res. 2004 Dec;39(6):398-404.Pubmed PMID: 15491344.

[25]. Koshy G, Corbet EF, Ishikawa I. A full-mouth disinfection approach to nonsurgical periodontal therapy--prevention of reinfection from bacterial reservoirs. Periodontol 2000. 2004;36:166-78.Pubmed PMID: 15330948.

[26]. Noguchi K, Ishikawa I. The roles of cyclooxygenase-2 and prostaglandin E2 in periodontal disease. Periodontal 2000. $2007 \mathrm{Feb} ; 43(1): 85-101$.

[27]. Ramesh A, Varghese S, Jayakumar ND, Malaiappan S. Comparative estimation of sulfiredoxin levels between chronic periodontitis and healthy patients - A case-control study. J Periodontol. 2018 Oct;89(10):1241-1248.Pubmed PMID: 30044495.

[28]. Paramasivam A, Priyadharsini JV, Raghunandhakumar S, Elumalai P. A novel COVID-19 and its effects on cardiovascular disease. Hypertens. Res. 2020 Jul;43(7):729-30. 
[29]. S G, T G, K V, Faleh A A, Sukumaran A, P N S. Development of 3D scaffolds using nanochitosan/silk-fibroin/hyaluronic acid biomaterials for tissue engineering applications. Int J Biol Macromol. 2018 Dec;120(Pt A):876885.Pubmed PMID: 30171951.

[30]. Del Fabbro M, Karanxha L, Panda S, Bucchi C, Doraiswamy JN, Sankari $\mathrm{M}$, et al. Autologous platelet concentrates for treating periodontal infrabony defects. Cochrane Database Syst Rev. 2018;11:CD011423.

[31]. Paramasivam A, Vijayashree Priyadharsini J. MitomiRs: new emerging microRNAs in mitochondrial dysfunction and cardiovascular disease. Hypertens Res. 2020 Aug;43(8):851-853.Pubmed PMID: 32152483.

[32]. Jayaseelan VP, Arumugam P. Dissecting the theranostic potential of exosomes in autoimmune disorders. Cell Mol Immunol. 2019 Dec;16(12):935-936. Pubmed PMID: 31619771.

[33]. Vellappally S, Al Kheraif AA, Divakar DD, Basavarajappa S, Anil S, Fouad $\mathrm{H}$. Tooth implant prosthesis using ultra low power and low cost crystalline carbon bio-tooth sensor with hybridized data acquisition algorithm. Comput. Commun. 2019 Dec 15;148:176-84.

[34]. Vellappally S, Al Kheraif AA, Anil S, Assery MK, Kumar KA, Divakar DD. Analyzing Relationship between Patient and Doctor in Public Dental Health using Particle Memetic Multivariable Logistic Regression Analysis Approach (MLRA2). J Med Syst. 2018 Aug 29;42(10):183.Pubmed PMID: 30155746

[35]. Varghese SS, Ramesh A, Veeraiyan DN. Blended Module-Based Teaching in Biostatistics and Research Methodology: A Retrospective Study with Postgraduate Dental Students. J Dent Educ. 2019 Apr;83(4):445-450.Pubmed PMID: 30745352.

[36]. Venkatesan J, Singh SK, Anil S, Kim SK, Shim MS. Preparation, Characterization and Biological Applications of Biosynthesized Silver Nanoparticles with Chitosan-Fucoidan Coating. Molecules. 2018 Jun 12;23(6):1429.Pubmed PMID: 29895803.

[37]. Alsubait SA, Al Ajlan R, Mitwalli H, Aburaisi N, Mahmood A, Muthurangan $\mathrm{M}$, et al. Cytotoxicity of different concentrations of three root canal sealers on human mesenchymal stem cells. Biomolecules. 2018 Sep;8(3):68.

[38]. Venkatesan J, Rekha PD, Anil S, Bhatnagar I, Sudha PN, Dechsakulwatana C, et al. Hydroxyapatite from cuttlefish bone: isolation, characterizations, and applications. Biotechnol Bioprocess Eng. 2018 Aug;23(4):383-93.

[39]. Vellappally S, Al Kheraif AA, Anil S, Wahba AA. IoT medical tooth mounted sensor for monitoring teeth and food level using bacterial optimization along with adaptive deep learning neural network. Measurement. 2019 Mar 1;135:672-7.

[40]. PradeepKumar AR, Shemesh H, Nivedhitha MS, Hashir MMJ, Arockiam S, Uma Maheswari TN, et al. Diagnosis of Vertical Root Fractures by Conebeam Computed Tomography in Root-filled Teeth with Confirmation by Direct Visualization: A Systematic Review and Meta-Analysis. J Endod. 2021 Aug;47(8):1198-1214.Pubmed PMID: 33984375.

[41]. R H, Ramani P, Tilakaratne WM, Sukumaran G, Ramasubramanian A,
Krishnan RP. Critical appraisal of different triggering pathways for the pathobiology of pemphigus vulgaris-A review. Oral Dis. 2021 Jun 21.Pubmed PMID: 34152662.

[42]. Ezhilarasan D, Lakshmi T, Subha M, Deepak Nallasamy V, Raghunandhakumar S. The ambiguous role of sirtuins in head and neck squamous cell carcinoma. Oral Dis. 2021 Feb 11.Pubmed PMID: 33570800.

[43]. Sarode SC, Gondivkar S, Sarode GS, Gadbail A, Yuwanati M. Hybrid oral potentially malignant disorder: A neglected fact in oral submucous fibrosis. Oral Oncol. 2021 Oct;121:105390.Pubmed PMID: 34147361.

[44]. Kavarthapu A, Gurumoorthy K. Linking chronic periodontitis and oral cancer: A review. Oral Oncol. 2021 Jun 16:105375.

[45]. Vellappally S, Al-Kheraif AA, Anil S, Basavarajappa S, Hassanein AS. Maintaining patient oral health by using a xeno-genetic spiking neural network. J. Ambient Intell. Humaniz. Comput. 2018 Dec 14:1-9.

[46]. Aldhuwayhi S, Mallineni SK, Sakhamuri S, Thakare AA, Mallineni S, Sajja R, et al. Covid-19 Knowledge and Perceptions Among Dental Specialists: A Cross-Sectional Online Questionnaire Survey. Risk Manag Healthc Policy. 2021 Jul 7;14:2851-2861.Pubmed PMID: 34262372.

[47]. Selvaggi G, Monstrey S, Van Landuyt K, Hamdi M, Blondeel P. The role of iodine in antisepsis and wound management: a reappraisal. Acta Chir Belg. 2003 Jun;103(3):241-7.Pubmed PMID: 12914356.

[48]. Hoang T, Jorgensen MG, Keim RG, Pattison AM, Slots J. Povidone-iodine as a periodontal pocket disinfectant. J Periodontal Res. 2003 Jun;38(3):3117.

[49]. Berkelman RL, Holland BW, Anderson RL. Increased bactericidal activity of dilute preparations of povidone-iodine solutions. J. Clin. Microbiol. 1982 Apr;15(4):635-9.

[50]. Perayil J, Menon KS, Biswas R, Fenol A, Vyloppillil R. Comparison of the efficacy of subgingival irrigation with $2 \%$ povidone-iodine and tetracycline $\mathrm{HCl}$ in subjects with chronic moderate periodontitis: A clinico microbiological study. Dent Res J (Isfahan). 2016 Mar-Apr;13(2):98-109.Pubmed PMID: 27076823

[51]. Alroudhan E, Gamal M, Ganji KK, Khan AM, Alsharari KN, Alruwaili MK, et al. The Effectiveness of Mouthwashes With Various Ingredients in Plaque Control: A Systematic Review and Meta-Analysis. Altern Ther Health Med. 2021 Apr 30. 